\title{
MANAGING OUR OLD GROWTH FORESTS ${ }^{1}$
}

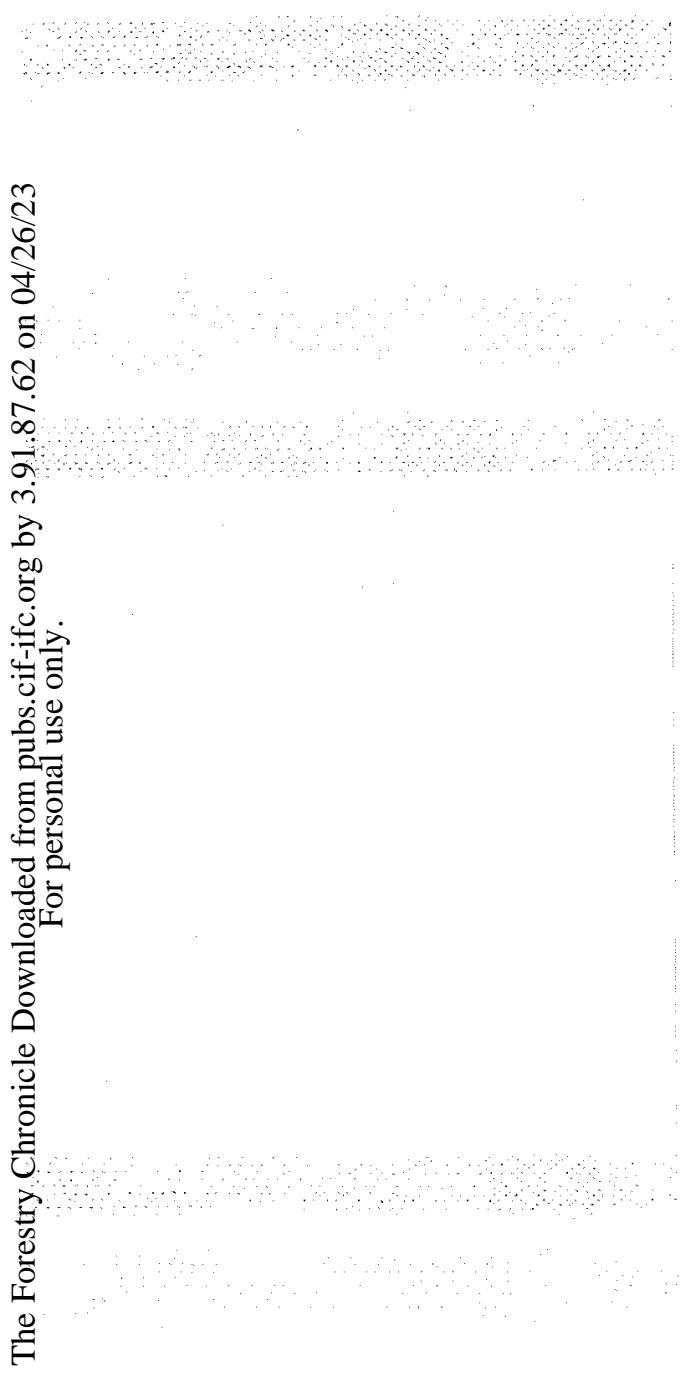

\section{By T. G. WRIGHT ${ }^{2}$}

These observations are confined to the coastal region of British Columbia, and more particularly to the Vancouver Forest District, which is the Province's major timber producing and manufacturing area. The total cut on the Vancouver District last year was 3,600 million board feet, or 59 per cent of the total cut in the Province.

Sixty-five per cent of the productive forest area of the Vancouver District is covered with old growth timber. Ninety-five per cent of the present cut is derived from mature forests, and for many decades to come the orderly liquidation of old growth stands will provide a major task in forest management.

If one word can describe the most important objective to be attained in managing this old growth timber asset, that word is utilization.

There is probably no place on the North American Continent which has moved forward more rapidly than British Columbia in the utilization of wood in the conversion plants. Indeed, the very excellence of utilization of residues at the mills has retarded utilization in the woods, because slabs and edgings are a cheaper source of raw material than are the chunks, tops and saplings which make up the residues after logging.

Even so, the improved standard of utilization in the mills has had a pronounced effect on increasing the value of logs. This fact, together with the growing needs of an expanding industry for accessible raw materials, has caused a steady improvement in utilization in the woods.

The building of roads to develop timber in British Columbia is of pressing importance. A large portion of the remaining timber lies on steep or rocky ground beyond the reach of existing roads. Gravel is scarce and road building is expensive. It would be safe to say that the industry on the Coast is spending a minimum of $\$ 15,000,000$ per year to build roads into undeveloped timber. Without this huge program, which must be continued for several decades to come, and which must be accompanied by an ever-increasing maintenance cost, effective management of old growth timber would not be possible.

It is worthy of note that the volumes per acre recovered in logging have been increasing steadily. The practices of re-logging and pre-logging have contributed to the improvement. An executive of one company commented that some of their re-logged settings were so clean that a woodpecker would have to bring his lunch. Speaking broadly, however, the greatest recoveries have been achieved more or less uniformly throughout the industry through the practice of cleaner prime logging.

The steady year-by-year improvements in utilization have resulted in an increased recovery of approximately 400 million board feet of timber annually, as compared with the volumes that would have been recovered on the same lands fifteen years ago. To express it another way, the volume of wood represented by this improved standard of utilization is equivalent to the annual increment on 800,000 acres of immature forest, or about 25 per cent of the total second growth area now being managed in the Vancouver District.

\footnotetext{
${ }^{1}$ Paper presented at the Western Forestry and Conservation Association December 5, 1956.

${ }^{a}$ Chief Forester, Canadian Forest Products L.td.
} 
It is likely that recoveries per acre will continue to increase. The hemlockbalsam types lend themselves to closer utilization because the logging residues can be used in the manufacture of pulp and newsprint. The installation of barking and chipping facilities for small logs will aid the trend toward more complete use of the old growth forest. The new drum barker and wood room for small wood now being constructed by MacMillan \& Bloedel Limited at Nanaimo is a fine example of this type of development.

Salvage logging is occupying an increasingly important role in old growth timber management. The logging of the Maquilla Burn in the Nimpkish Valley provides a good example of a large scale salvage operation. This fire, which swept through 180 million feet of timber in 1952, has been 80 per cent salvaged at the present date. The salvage of blowdown patches, beetle-killed timber, fire-killed fringes, windfalls and snags has become a routine part of logging operations on the Coast.

Intensive fire protection is accepted today as a matter of course. Still, we must never become complacent, for we know that many dry and hazardous seasons lie ahead. Studies of the old growth Douglas fir stands on the British Columbia Coast reveal that a major fire or series of fires has occurred just about every century for the past thousand years. For example, according to research carried out by Mr. Ralph Schmidt of the B.C. Forest Service, two million acres of forest land on Vancouver Island were swept by massive conflagrations three hundred years ago. This evidence serves as a warning that we must be ever watchful, even if we have a lengthy period with a good fire experience.

Greatly accelerated efforts in the direction of insect and disease control have been expended in recent years. The project now being carried out in the severe black headed budworm infestation on northern Vancouver Island is a good example. Under the leadership of Mr. R. R. Lejeune of the Federal Government and Mr. W. S. Hepher of Alaska Pine and Cellulose Limited, five logging companies and the Provincial and Federal Governments have joined forces to conduct a survey of the infestation and to conduct experimental aerial spraying. The infestation now covers an area of $1,800,000$ acres, and the Committee is giving careful study to the possible necessity of launching a full scale attack on the pests in 1957.

Old growth timber can be managed more effectively if careful analysis is made of individual stands. There is a too-common tendency to lump all mature stands together into one broad "old growth" classification, in spite of the fact that there is perhaps as much variation in old growth in respect to site, age, stocking and thrift as there is in immature stands. Many so-called old-growth stands are very sound and are adding substantial volume and quality increment, while other stands are deteriorating rapidly. Speaking broadly, the future timber balance sheet will be improved if decadent stands can be given priority in the cutting plan. Stands which occupy high sites also deserve early attention, because it is desirable to release the high yield capacity of these lands as soon as possible, and because these stands frequently are very 
defective. Crown Zellerbach Canada Limited has given careful attention to this problem by making extensive pathological studies of its timber with a view to planning the wisest management program.

The management of second growth is so closely related to the management of old growth timber that it is hard to say where one begins and the other ends. The most important period in second growth management is the interval immediately after logging when the new crop is becoming established. The promptness, completeness and composition of the regeneration are strongly influenced by the plan of action followed at the time of logging. It is perhaps axiomatic, then, that one of the greatest opportunities for managing the second growth crop comes at the time of harvesting the old growth.

As a result, intensive efforts are being made today to provide a good natural seed supply, to dispose of slash with great care, and to plant any blanks that do not re-stock naturally. A few years ago Canadian Forest Products Ltd. commenced the practice of planting the better sites the year after logging using stock grown from seed collected near the planting area. British Columbia Forest Products Ltd. has established a seed improvement stand, or "seed orchard", from which all but the best trees have been eliminated, in order that superior seedlings can be grown.

The added yields that can be achieved through more complete stocking and earlier stand establishment, as well as improvement in stand quality through the growing of well-spaced, superior crop trees, suggest that the nominal added costs of prompt regeneration will be more than balanced by the increased economic returns. This policy also permits greater flexibility in the logging plan for the mature timber, because the regeneration does not become so completely dependent upon the reservation of seed tree blocks. Furthermore, it has been our Company's experience that staggered settings have not always been effective in providing for a new crop.

Looking to the future of old growth management on the Vancouver District, it is interesting to note that for each acre of the mature Douglas fir types there are more than four acres of hemlock-balsam types, so that we must give careful attention to the problems of management in the pulp types. On the basis of our comparatively limited experience in these stands, certain interesting possibilities appear to merit study.

For example, it appears that the only reason Douglas fir is not growing today in many of these wet belt stands is that they have had no fire history, at least during the period since the present climax forests were established. Many of the finest fir stands on the Coast, such as in the Nitinat River, at Kyuquot Sound and in the Gold River-to name only a few examples-are growing in areas where the annual rainfall is well over 100 inches. Adjacent to these stands are large areas of pulp types where site conditions are the same. Douglas fir is not growing on these sites today, however, because the great fires which swept across Vancouver Island in the past did not extend into the pulp areas and clear the ground so the fir seedlings could become established. 
Those who believe that mixed fir-hemlock stands are desirable because of their greater resistance to windthrow, insects and disease believe that the total area of land growing Douglas fir could be greatly increased-perhaps nearly doubled-if the necessary planting program were undertaken. The sweep of the black-headed budworm across northern Vancouver Island during the past two years has provided good cause to doubt the advisability of encouraging pure stands of any species. It is possible that the yields of mixed fir-hemlock stands would exceed the yield of pure hemlock stands, and we must not ignore the fact that fir stumpage prices-both for old growth and second growthare remaining well in the lead of hemlock prices, in spite of all the recent economic trends which have strengthened the value of hemlock logs.

I believe that greater stress should be placed on area regulation in planning future cutting budgets. Area regulation creates the maximum incentive to achieve full utilization, and it checks the conservative tendencies which often arise in making volume and yield estimates under volume regulation. If we are too conservative we will only impede the attainment of the objective of maximum wood production.

The accessible parts of the Lower Coast which have been heavily cut in the past are slowly adjusting themselves to a sustained yield basis. This action is owing in large part to the Provincial Government's management licence and public working circle policies. At the same time, most of the operations which are not under government regulations are adjusting voluntarily to a sustained yield basis, because economic self-interest dictates that this is the wisest policy.

Many benefits have been derived from the so-called over-cutting which has taken place on the Lower Coast in the past. It is truly a happy circumstance that the development of the accessible stands over the past seventy years has built up British Columbia's world trading position, aided the expansion of its industries, and built its roads and communities. Because of the very fact of heavy cutting in the Douglas fir types, there is a better growing stock distribution in fir than in any other species. Sixty-five per cent of the fir types are now composed of a fairly well balanced immature forest, while only twenty per cent of the hemlock types consist of second growth stands. Furthermore, I believe it is safe to say that we are practically on sustained yield for Douglas fir. The present fir cut of about 1,400 million board feet annually can be sustained at or near that level indefinitely, and this knowledge can have an important influence on government and industrial management plans.

Because of past heavy cutting in the fir belt, we are now in a position to commence practicing intensive management in the older second growth stands. This can have a definite influence on old growth management, because there is a fringe of mature timber that, because of low volumes per acre, low quality or high cost of logging, may never be logged. Indeed, the wisest plan of management for many stands may be to leave them untouched, never to be logged, because it would constitute an economic loss to go beyond the point where we are saving wood and wasting money. We may produce more wood by leaving the scrub ridge tops alone and practicing intensive silviculture in the accessible second growth stands. 
The great problem on this Coast is not so-called local over-cutting, but instead is regional undercutting. The evidence submitted before the Royal Commission on Forestry showed that the annual cut on the British Columbia Coast can be increased by at least forty per cent. The rate of cut on the 65 million acres of forests in the Interior of the Province can be increased by a much greater proportion.

It will be to the great and lasting benefit of British Columbia to accelerate the harvesting of the over-mature forest up to the level of the sustained yield capacity just as rapidly as economic conditions will permit, and to transform the millions of acres of static old growth lands into dynamic, growing crops for the future. 